\title{
Fabrication of tissue-engineered vascular grafts using low sustained intraluminal pressure to sod human adipose-derived stromal vascular fraction cells onto ePTFE
}

\begin{abstract}
Every year millions of Americans are affected by cardiovascular and peripheral arterial diseases. When a patient's own blood vessels are not suitable for surgical intervention, alternative graft sources are necessary. In this study, the lumens of expanded polytetrafluoroethylene (ePTFE) conduits were coated with freshly isolated adipose-derived stromal vascular fraction (SVF) cells or cultured adipose-derived stromal cells (ASCs) by a single-stage method called "pressure sodding," using low sustained intraluminal pressure. ePTFE vascular conduits were sodded in as short as 5 minutes. The luminal surface coverage of grafts immediately following pressure sodding and subsequent exposure to physiological luminal flow was evaluated by nuclear staining of the attached cells to the conduit. Cell behavior associated with the sodding process and subsequent shear stress via luminal flow was examined through tissue factor quantification. After exposure to luminal flow at a rate approximating physiological shear in human coronary arteries, the sodded cells remained on the ePTFE conduits. When cultured SVF cells (ASCs, attached stromal cells) were used, average normalized tissue factor levels increased with the application of a luminal flow following the cell sodding process. However, when freshly isolated SVF cells were used, the average normalized tissue factor did not significantly change even after luminal flow. When these cell-coated vascular grafts were implanted into the carotid arteries of dogs, they remained patent for at least 140 days. This novel method of pressure sodding is critical to rapid fabrication of tissue-engineered vascular grafts which can facilitate a successful point-of-care treatment for a number of vascular diseases.
\end{abstract}

Keywords: adipose-derived stromal vascular fraction cells, adipose-derived stromal cells, expanded polytetrafluoroethylene, vascular graft, tissue engineering, pressure sodding, tissue factor
Volume 2 Issue 3 - 2017

\author{
Hyun Joon Paek,' Stuart Williams, ${ }^{1,2}$ Anthony \\ Yang,' Courtney Kim,' Shannon Iwami,' Todd \\ Case, ${ }^{3}$ Scott Berman, ${ }^{4}$ Eugene Boland, ${ }^{5}$ Paul \\ Kosnik' \\ 'Tissue Genesis, LLC, USA \\ ${ }^{2}$ Cardiovascular Innovation Institute, University of Louisville, \\ USA \\ ${ }^{3}$ Profiles Cosmetic Surgery and Skin Care, USA \\ ${ }^{4}$ Southern Arizona Vascular Institute, USA \\ ${ }^{5}$ Techshot Inc., USA \\ "These authors contributed equally to this manuscript.
}

\begin{abstract}
Correspondence: Hyun Joon Paek, Tissue Genesis, 810 Richards Street, Suite 100 Honolulu, HI 68I3, USA, Tel 8087725590, Fax 8085399345,Email jpaek@tissuegenesis.com
\end{abstract}

Received: January 29, 2017 | Published: March 23, 2017
Abbreviations: ePTFE, expanded polytetrafluoroethylene; SVF, stromal vascular fraction; ASCs, adipose-derived stromal cells; CVD, cardio vascular disease; PAD, peripheral arterial disease; PET, polyethylene terephthalate; DPBS, dulbecco's phosphate buffered saline; HCM, human complete medium; BBI, bisbenzimide; SEM, scanning electron microscopy; BOS, bio-optimization system

\section{Introduction}

Vascular diseases, including cardiovascular (CVD) and periphera arterial diseases (PAD), affect over 87 million Americans every year, and approximately one in three Americans have some form of vascular disease. In the United States, 427,000 coronary artery bypass surgeries were performed on 249,000 patients in $2004 .{ }^{1}$ Historically, long saphenous vein autografts have been commonly used for such surgeries. However, this type of vessel often deteriorates when exposed to increased flow and arterial circulation pressure. ${ }^{2}$ Up to $15 \%$ of saphenous vein grafts typically lose patency within the first year following bypass surgery. ${ }^{3}$ Additionally, when accelerated atherosclerotic changes become observed in some of the transplanted vessels, there is a $40 \%$ decrease in patency, and $50 \%$ of the grafts show significant stenoses. ${ }^{4,5}$ Due to their superior patency, arterial bypass conduits are now widely accepted as the best choice for surgical revascularization. However, the availability of internal mammary artery conduits are limited, and late closure in $10 \%$ of such conduits occur after 10-15years. ${ }^{6,7}$ When saphenous veins and internal mammary arteries are not available or usable, alternative forms of vessel become necessary, which include arm vein, human umbilical vein, and cryopreserved allografts. ${ }^{8-12}$ However, the development of fibrous intimal hyperplasia, which leads to stenosis has been observed in these vein grafts as well. ${ }^{13}$

Artificial polymeric grafts, such as polyethylene terephthalate (PET), and polytetrafluoroethylene (PTFE), are also used as alternatives for larger vessels. ${ }^{2}$ However, acute thrombogenecity, anastomotic intimal hyperplasia, aneurysm formation, infection, and progression to atherosclerotic diseases have been challenges for polymeric replacement conduits under $6 \mathrm{~mm}$ in diameter. These synthetic vessels are considerably sub-optimal for use as a conduit in coronary artery bypass surgeries. ${ }^{14}$

The primary goal of any tissue-engineering approach to vessel replacement is to coat the lumen of a synthetic conduit with autologous endothelial cells, so that a non-thrombogenic and non-immunogenic 
surface can be achieved. ${ }^{15,16}$ Endothelialized expanded PTFE (ePTFE) has demonstrated similar patency to autologous saphenous vein in infrainguinal bypass operations ${ }^{17}$ However, the main disadvantages of using endothelialized grafts include prolonged in-vitro culture of cells prior to and during graft development and the length of time required to prepare such grafts. Long-term in-vitro culture increases the risk of contamination as well as increases costs of labor and materials. Moreover, tissue-engineered grafts could take up to 8 weeks from the point of tissue harvest to obtain a fully functioning endothelialized graft. ${ }^{18}$ This two-staged preparation of conventional tissue-engineered vascular grafts allows for an immediate point-of-care treatment to be impossible.

We hypothesized that tissue-engineered and clinically-viable vascular grafts can be achieved, using a single-stage seeding method with freshly isolated autologous adipose-derived SVF cells. In this study, we developed a novel single-stage cell deposition method based on the sodding techniques originally described by Williams et al. ${ }^{19,20}$ This method utilizes a biochamber and bioreactor system (Bio-Optimization System [BOS] ${ }^{\mathrm{TM}}$, Tissue Genesis, Inc., Honolulu, HI). The BOS provides a constant, non-pulsatile flow for pressure sodding while allowing automatic monitoring and recording of flow rate and temperature. The ability of the biochamber and BOS system to support rapid deposition of adipose derived cells, using both freshly-isolated stromal vascular fraction (SVF) and culturederived adipose-derived stromal cells (ASCs), was evaluated in this study. Tissue factor expression, which is involved in the activation of blood coagulation via the extrinsic pathway, of the sodded cells was measured to assess biological complications associated with pressure sodding. ${ }^{21,22}$ Optimized vascular grafts were subsequently implanted into the carotid arteries of dogs and then observed for $140 \pm 1$ days. Following explantation, the vascular grafts were evaluated for cell coverage and patency.

\section{Materials and methods}

\section{Cell isolation and culture}

Following informed consent, adipose tissue was obtained from patients undergoing routine cosmetic lipoplasty. Evacuated adipose tissue and fluid from abdominal lipoplasty was collected in a sterile container and transported from the operating suite to the laboratory. Using sterile techniques, each specimen was washed three times in a metal sieve with Dulbecco's Phosphate Buffered Saline (DPBS, Invitrogen, Carlsbad, CA) supplemented with $0.1 \%$ bovine serum albumin (BSA, Sigma, St. Louis, MO). Fifty milliliters (mL) of washed tissue were then equally divided into four $50 \mathrm{~mL}$ conical tubes by volume. Then collagenase, purified according to the previously described method, ${ }^{23}$ was added to the conical tubes containing the washed tissue at $1: 1(\mathrm{v} / \mathrm{v})$. Tissue digestion was carried out at $37^{\circ} \mathrm{C}$ with constant agitation for 45 minutes. Following digestion, the tubes were centrifuged at $700 \mathrm{xg}$ for 5 minutes, and supernatants were discarded. The cell pellets were washed twice and re-suspended in Media 199E (Invitrogen, Carlsbad, CA) supplemented with $1 \%$ BSA. Five million viable cells were added to each gelatin-coated T-75 flask (Becton Dickinson Labware, Bedford, MA) containing Human Complete Medium (HCM), Media 199E supplemented with fetal bovine serum (Gemini Bio-Product, West Sacramento, CA), $5 \mathrm{mM}$ HEPES (Sigma, St. Louis, MO), 1\% L-glutamine (Invitrogen, Carlsbad, CA) and EGM ${ }^{\mathrm{TM}}-2 \mathrm{MV}$ BulletKit ${ }^{\mathrm{TM}}$ (Lonza, Basel, Switzerland). Cells were allowed to adhere to the flask overnight at $37^{\circ} \mathrm{C} / 5 \% \mathrm{CO}_{2}$. Flasks were then washed twice with DPBS to remove any non-adherent cells. Fresh HCM was added, and adherent cells were cultured to near confluency.

\section{ePTFE preparation}

Impra ePTFE grafts (Bard Peripheral Vascular Inc, Tempe, AZ), with an inner diameter of $4 \mathrm{~mm}$ and internodal distance of $30 \mu \mathrm{m}$ were utilized for this study. Graft segments were tangentially transected and then posted onto a $1 / 8$ " straight-through barb connector (Value Plastics, Fort Collins, CO) at each end (Figure 1A). Grafts were slipped onto the barbs and tightly attached using PTFE thread. The length of graft between each barb head was $2 \mathrm{~cm}$ (the usable length of the graft). Posted grafts were then installed into a custom tubular biochamber (Figure 1B) and sterilized using ethylene oxide. Grafts were then denucleated by filling each graft with $70 \%$ reagent ethanol through the interstices of its lumen until the ethanol passed through the graft wall and each graft was completely submerged in reagent ethanol within the biochamber. Grafts remained in ethanol for 10 minutes. Successful denucleation resulted in a semi-translucent ePTFE conduit with no opaqueness visible on the surface of the conduit and no air bubbles present on the lumen of the conduit (Figure 1A). Grafts were then flushed with suspension medium three times to eliminate ethanol in the grafts and biochambers.

\section{Pressure sodding}

The luminal surface of the conduits was sodded with a defined total cell population, and the freshly isolated SVF cell or in-vitro cultured ASC densities were relative to the graft luminal surface area (Table 1). First, biochambers containing sterile and denucleated vascular conduits were connected to both a 3-way stopcock and a flow path in the BOS (Figure 1B). The flow rate in the BOS was set to approximately $100 \mathrm{~mL} / \mathrm{min}$. The cell suspension was injected into the flowpath through the 3-way stopcock at an approximate rate of $0.1 \mathrm{~mL}$ per second, which allowed for the prevention of introducing air bubbles into the system. Once the cell suspension flowed into the lumen of the conduit, the cell culture medium started to permeate through the conduit wall and into the space of the biochamber at $100 \mathrm{~mL} / \mathrm{min}$, due to the blockage of the flowpath downstream of the conduit by clamping (Figure 1C). The interstitial flow deposited the cells on the luminal surface of the conduit because the pores of the ePTFE conduit were smaller than the cell's diameter. This sodding process via transluminal flow was continued for 5 minutes. A portion of the sodded grafts was immediately evaluated for cell coverage and secretion of TF, and the remaining graft was exposed to an approximation of physiological shear forces in human coronary arteries by establishing luminal flow of $100 \mathrm{~mL} / \mathrm{min}\left(\sim 8\right.$ dynes $\left./ \mathrm{cm}^{2}\right)$ for 30 minutes. Table 1 summarizes the sodding and luminal flow conditions for each experiment.

\section{Evaluation of grafts}

Immediately following completion of the pressure sodding using the BOS, sodded grafts were removed from the biochambers and cut into three pieces: proximal, center, and distal segments. The proximal and the distal segments were immediately fixed in HistoCHOICE ${ }^{\circledR}$ (AMRESCO Inc., Solon, OH) for bisbenzimide (BBI) staining (Molecular Probes, Carlsbad, CA). The center segments, which were approximately $1 \mathrm{~cm}$ in length, were transferred to microcentrifuge tubes containing $1 \mathrm{~mL}$ of Tris-buffered saline (Sigma Aldrich, St. Louis, MO) supplemented with 1\% Triton X-100 (EM Science, Gibbstown, NJ) for cell lysis. The cells on the center segment of the 
grafts were then lysed by 4 cycles of freeze-thaw using alternating liquid nitrogen and warm water bath submersion and sonication for 15 minutes. The tubes were then placed in the disruptor for 15 minutes followed by an 18 -hour incubation period at $4^{\circ} \mathrm{C}$. Finally, the center segments were removed from the microcentrifuge tubes and fixed in
HistoCHOICE ${ }^{\circledR}$ for BBI staining to confirm complete dissociation of cells. The tubes containing total cell lysates were then centrifuged at $16,300 x \mathrm{x}$ for 10 minutes. The supernatant was collected for tissue factor assessment and the pelleted lysates were collected for DNA quantification.

Table I Sodding cell densities and luminal flow conditions

\begin{tabular}{|c|c|c|c|c|c|c|}
\hline & & \multirow{2}{*}{$\begin{array}{l}\text { Sodding density } \\
\left(\times 10^{5} \text { cells } / \mathrm{cm}^{2}\right)\end{array}$} & \multicolumn{2}{|c|}{ Transluminal flow } & \multicolumn{2}{|c|}{ Luminal flow } \\
\hline & & & Flow & Duration & Shear & Duration \\
\hline \multirow{2}{*}{ Experiment I } & Group I & 5 (cultured ASCs) & $100 \mathrm{~mL} / \mathrm{min}$ & $5 \mathrm{mins}$ & & \\
\hline & Group II & 5 (cultured ASCs) & $100 \mathrm{~mL} / \mathrm{min}$ & $5 \mathrm{mins}$ & $8 \mathrm{dyn} / \mathrm{cm}^{2}$ & 30 minutes \\
\hline \multirow{2}{*}{ Experiment II } & Group I & 5 (cultured ASCs) & $100 \mathrm{~mL} / \mathrm{min}$ & $5 \mathrm{mins}$ & & \\
\hline & Group II & 2 (cultured ASCs) & $100 \mathrm{~mL} / \mathrm{min}$ & $5 \mathrm{mins}$ & & \\
\hline \multirow{2}{*}{ Experiment III } & Group I & 2 (freshly isolated SVF cells) & $100 \mathrm{~mL} / \mathrm{min}$ & $5 \mathrm{mins}$ & & \\
\hline & Group II & 2 (freshly isolated SVF cells) & $100 \mathrm{~mL} / \mathrm{min}$ & $5 \mathrm{mins}$ & $8 \mathrm{dyn} / \mathrm{cm}^{2}$ & 30 minutes \\
\hline
\end{tabular}
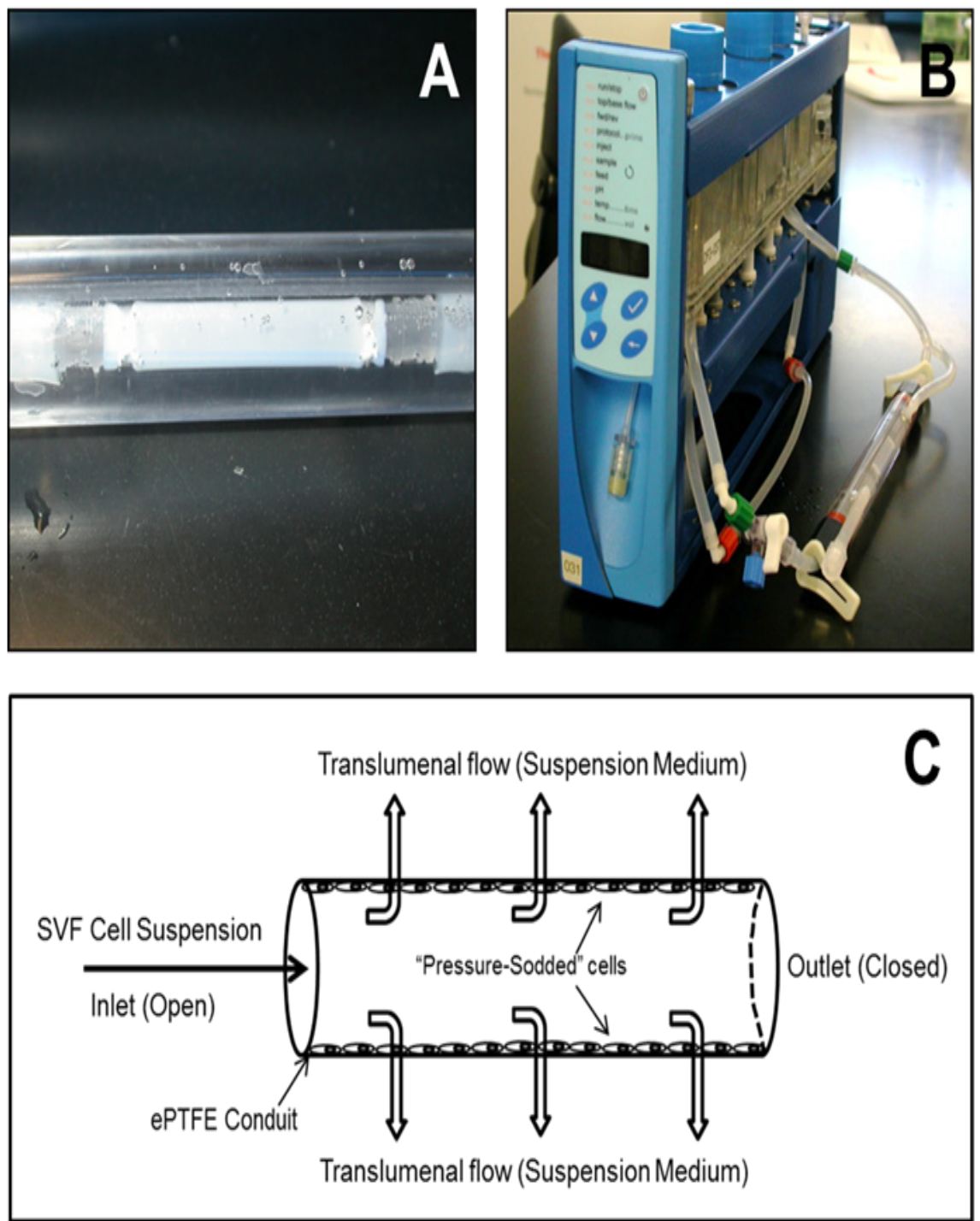

Figure I (A) 4-cm ePTFE conduit loaded into a vascular biochamber. (B) Vascular biochamber connected to the Bio-Optimization System ${ }^{\mathrm{TM}}$. (C) Schematic representation of pressure sodding. 


\section{Evaluation of tissue factor}

Human tissue factor was measured by enzyme-linked immunosorbent assay (ELISA; American Diagnostica Inc., Stamford, CT). The assay was performed according to the manufacturer's instructions. Protein levels were normalized to total DNA content. DNA in lysates was extracted and quantified using a DNeasy ${ }^{\circledR}$ Tissue Kit (Qiagen, Valencia, CA) and Quant-iTÔ PicoGreen ${ }^{\circledR}$ dsDNA Assay Kit (Molecular Probes, Carlsbad, CA), respectively.

\section{BBI staining}

For immediate and rapid evaluation of the sodded vascular grafts, BBI was used to stain the nuclei of sodded cells to provide a representative image of cell coverage over the vascular conduit. A BBI stock solution was prepared by adding $5 \mathrm{mg}$ of BBI powder to $1 \mathrm{~mL}$ of ultrapure water. A working solution was then prepared by adding three drops of the stock solution to $10 \mathrm{~mL}$ of DPBS. Graft segments were removed from HistoCHOICE ${ }^{\circledR}$ and rinsed in DPBS The proximal and distal cuts (about $2 \mathrm{~mm}$ in width) were made from the graft and placed in $1.5 \mathrm{~mL}$ microcentrifuge tubes containing the BBI working solution and incubated for 15 minutes at room temperature. After the incubation period, the grafts were rinsed in DPBS then opened lengthwise and placed on a slide with the luminal surface facing upward. A glass cover slip was placed over each graft segment and secured with transparent tape at each end. Specimens were kept protected from light until imaged.

Grafts were imaged using the DAPI setting on the Olympus IX71 Epifluorescence Microscope and Microsuite Biological Suite Software (Olympus Imaging America Inc., Center Valley, PA). Cell coverage on the lumen of the graft was visually analyzed. Cell nuclei stained fluorescent blue against the dark blue background (graft luminal surface).

\section{In vivo evaluation of vascular graft}

All animal studies were performed based on a protocol approved by the Institutional Animal Care and Use Committee, at Surpass Inc (Osceola, WI). The falciform ligament adipose tissue was procured from each canine, and ASCs were isolated using the protocol described above. The ePTFE conduits were manually pressure sodded with SVF cells at a concentration of $2 \times 10^{5}$ cells $/ \mathrm{cm}^{2}$ under sustained low pressure less than or equal to 5 psi. Untreated, off-the-shelf ePTFE conduits served as a control. Angiography was used to visualize vessel anatomy, and the vessel diameter at the implant site was measured. The left and right common carotid arteries were exposed through a single ventral midline neck incision or separate lateral incision in canines, weighing $20-25 \mathrm{~kg}$. An $8-10 \mathrm{~cm}$ segment of the right or left carotid artery was mobilized from the surrounding tissue. Following systemic anticoagulation and subsequent clamping of the proximal and distal ends of the mobilized segment, approximately $6 \mathrm{~cm}$ of the arterial segment was removed and replaced with a $6 \mathrm{~cm}$ segment of the test or control article. The test or control graft was then implanted in an end-to-end manner using a single running or double running polypropylene suture for each anastomosis. Graft patency was periodically monitored using ultrasound imaging throughout the study period, and the implanted vascular grafts were explanted at $140 \pm 1$ days. Selected segments of the explanted grafts were evaluated for patency, endothelialization, neointimal thickness, and the presence or absence of thrombosis and necrosis, using standard histology protocols.

\section{Scanning electron microscopy}

High magnification, high resolution imaging of samples was performed using scanning electron microscopy (SEM) (JSM-820 scanning electron microscope, JEOL Ltd.). Prior to imaging, samples were fixed in 3\% glutaraldehyde, cut longitudinally, and processed via dehydration, critical point drying, and sputter coating.

\section{Statistical analysis}

Data are shown as mean \pm standard error of the mean (SE). A Student t-test was used to examine the statistical significance of differences found between two means. Differences were considered statistically significant at a p-value $<0.05$.

\section{Results}

\section{Effects of luminal flow}

The luminal surface of the ePTFE conduits was successfully coated at $5 \times 10^{5} \mathrm{ASCs} / \mathrm{cm}^{2}$ by pressure sodding using the BOS, as shown by the nuclei staining with BBI in Figure $2 \mathrm{~A}$. Over $70 \%$ of the grafts subjected to luminal flow for 30 minutes, which approximated physiological shear in human coronary arteries, maintained their cell coverage. A portion of the grafts was subjected to cell lysis, and lysis efficiency was confirmed by the absence of positive BBI staining, as shown in Figure 2B. Following lysis, levels of tissue factor were measured and total DNA was quantified. Total DNA quantities were normalized to the luminal area of the ePTFE conduits. There was a statistically significant decrease in total DNA collected from the grafts that were exposed to luminal flow for 30 minutes $(199 \pm 66 \mathrm{ng} /$ $\mathrm{cm}^{2}$ ) compared to grafts not exposed to luminal flow (396 $\pm 53 \mathrm{ng} /$ $\mathrm{cm}^{2}$ ) (Figure 3A), suggesting some cells detached from the conduit during luminal flow. When tissue factor level was normalized to total DNA and the luminal area of the ePTFE conduits, both conditions resulted in a comparable tissue factor production with no statistically significant difference (Figure 3B).
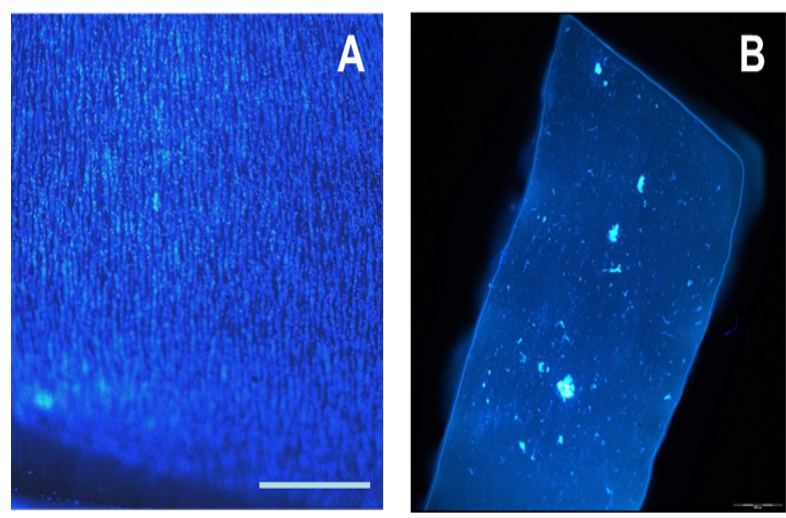

Figure 2 Images of BBI staining (A) post-sodding of ePTFE conduit with ASCs and $(B)$ post-lysis. (scale bar $=500 \mu \mathrm{m}$ ).

\section{Effects of sodding density}

Grafts were sodded with cultured ASCs at two concentrations; $2 \times 10^{5}$ cells $/ \mathrm{cm}^{2}$ and $5 \times 10^{5}$ cells $/ \mathrm{cm}^{2}$. Conduits sodded at $2 \times 10^{5}$ cells $\mathrm{cm}^{2}$ maintained approximately $80 \%$ cell coverage based on qualitative evaluation of BBI staining (Figure 2A). As shown in Figure 4A, total DNA quantity of grafts sodded with $2 \times 10^{5}$ cells $/ \mathrm{cm}^{2}$ was $202 \pm 26 \mathrm{ng} /$ $\mathrm{cm}^{2}$ which was significantly lower in comparison to the grafts sodded at $5 \times 10^{5}$ cells $/ \mathrm{cm}^{2}$ with $396 \pm 53 \mathrm{ng} / \mathrm{cm}^{2}$. Such a difference can be 
attributed to the lower seeding density. When tissue factor levels were normalized to total DNA and the luminal area of the ePTFE conduit, the grafts sodded at $2 \times 10^{5}$ cells $/ \mathrm{cm}^{2}$ showed a significantly lower level of tissue factor at $0.56 \pm 0.07 \mathrm{pg} / \mathrm{ngcm}^{2}$ compared to $2.2 \pm 0.7 \mathrm{pg} / \mathrm{ngcm}^{2}$ found in the grafts sodded at $5 \times 10^{5}$ cells $/ \mathrm{cm}^{2}$ (Figure 4B). Based on the cell coverage and levels of tissue factor, we have determined that $2 \times 10^{5}$ cells $/ \mathrm{cm}^{2}$ is a more optimal cell sodding density.

A

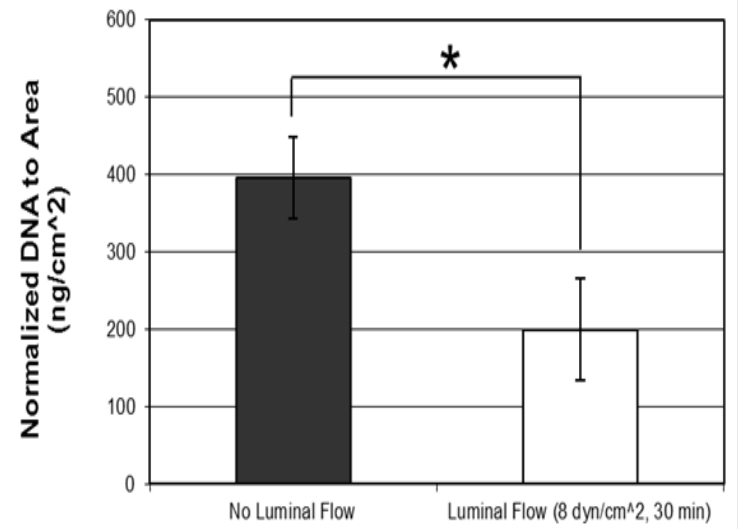

Post-Sodding Treatment

B

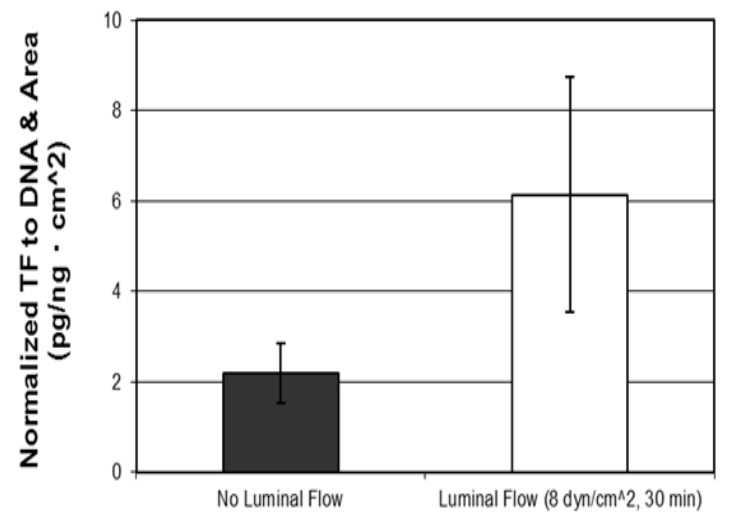

Post-Sodding Treatment

Figure 3 Effects of luminal flow applied after sodding cultured ASCs onto ePTFE conduits. Luminal flow applied for 30 minutes post sodding is equivalent to 8 dynes $/ \mathrm{cm}^{2}$ of shear. (A) Normalized DNA quantity to the luminal area of the grafts and $(B)$ normalized tissue factor to the luminal area and total DNA. Data is shown as mean \pm SE. * denotes a statistically significant difference between the two means $(p<0.05)$; no luminal flow $(n=8)$, luminal flow $(n=5)$.

\section{Use of freshly-isolated SVF cells}

Approximately $8 \times 10^{5}$ viable SVF cells were isolated per $\mathrm{mL}$ of lipoaspirated human adipose tissue. Freshly isolated SVF cells were immediately pressure sodded at $2 \times 10^{5} \mathrm{cells} / \mathrm{cm}^{2}$ onto the ePTFE conduit as described. Grafts were analyzed both immediately after a 5-minute sodding regime and after 30 minutes of luminal flow $\left(\sim 8\right.$ dynes $\left./ \mathrm{cm}^{2}\right)$. After greater than $80 \%$ cell coverage was confirmed by BBI staining, tissue factor and DNA quantifications were performed. Although a moderate increase in total DNA $\left(140 \pm 32 \mathrm{ng} / \mathrm{cm}^{2}\right.$ vs. $\left.81 \pm 9 \mathrm{ng} / \mathrm{cm}^{2}\right)$ was observed in the grafts subjected to luminal flow, the increase was not statistically significant (Figure 5A). A decrease in tissue factor levels in grafts exposed to luminal flow $\left(0.7 \pm 0.2 \mathrm{pg} / \mathrm{ngcm}^{2}\right.$ vs. $0.9 \pm 0.1 \mathrm{pg} /$ $\mathrm{ngcm}^{2}$ ) was also observed, however, not found significant (Figure $5 \mathrm{~b}$ ).
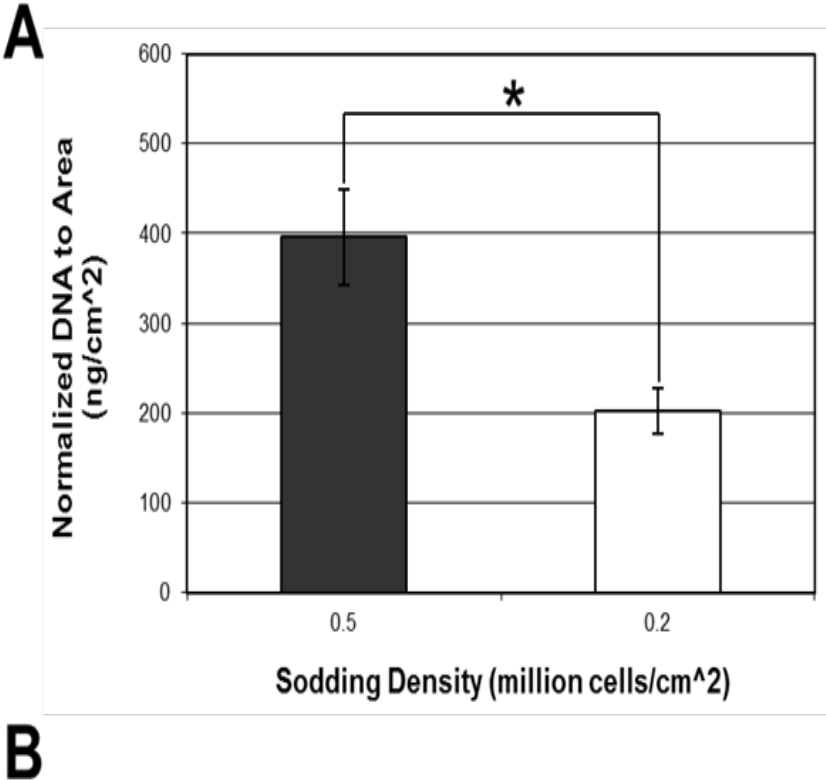

Sodding Density (million cells $/ \mathrm{cm}^{\wedge} 2$ )

B

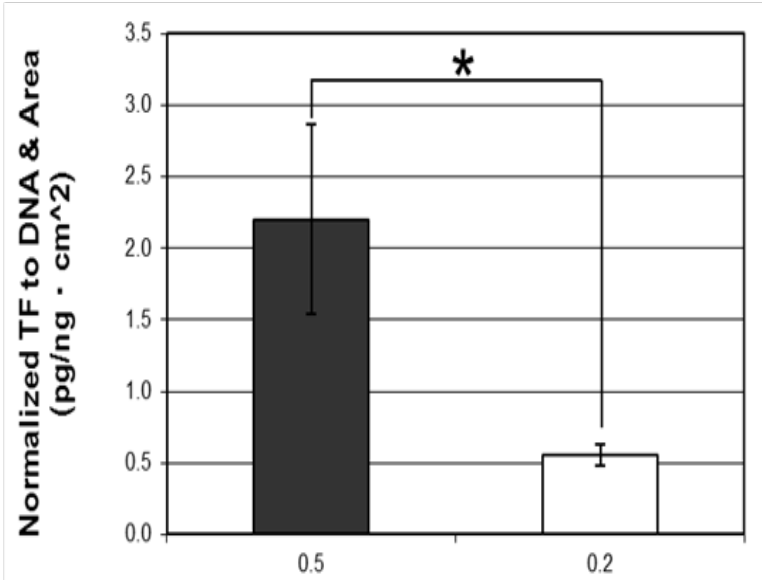

Sodding Density (million cells $/ \mathrm{cm}^{\wedge} 2$ )

Figure 4 Effects of sodding density of cultured ASCs. (A) Normalized DNA quantity to the luminal area of the grafts and (B) normalized tissue factor to the luminal area and total DNA. Data is shown as mean \pm SE. * denotes a statistically significant difference between the two means $(p<0.05)$; $0.5 \times 10^{6} \mathrm{cells} / \mathrm{cm}^{2}(\mathrm{n}=8), 0.2 \times 10^{6} \mathrm{cells} / \mathrm{cm}^{2}(\mathrm{n}=13)$.

\section{Explanted graft evaluation}

Based on angiography, occlusion of control grafts initiated on or prior to Day 28 and increased with study duration. At the end of the study, $50 \%$ of the control grafts were ultimately not patent (data not shown). Minimal to no endothelialization was observed in the occluded grafts (Figures 6A \& 6C). Variable amounts of amorphous extracellular matrices and fibrous material were present in the neointima of control grafts (Figure 6C). In contrast, all test grafts remained patent throughout the study. Histological evaluation showed complete endothelialization of the test grafts, with a thinner neointima than that in the control group (Figures 6B \& 6D). Erosion of the cell surface was more prevalent in the control grafts compared to the test cohorts based on SEM observation (Figures 6E \& 6F). 
A

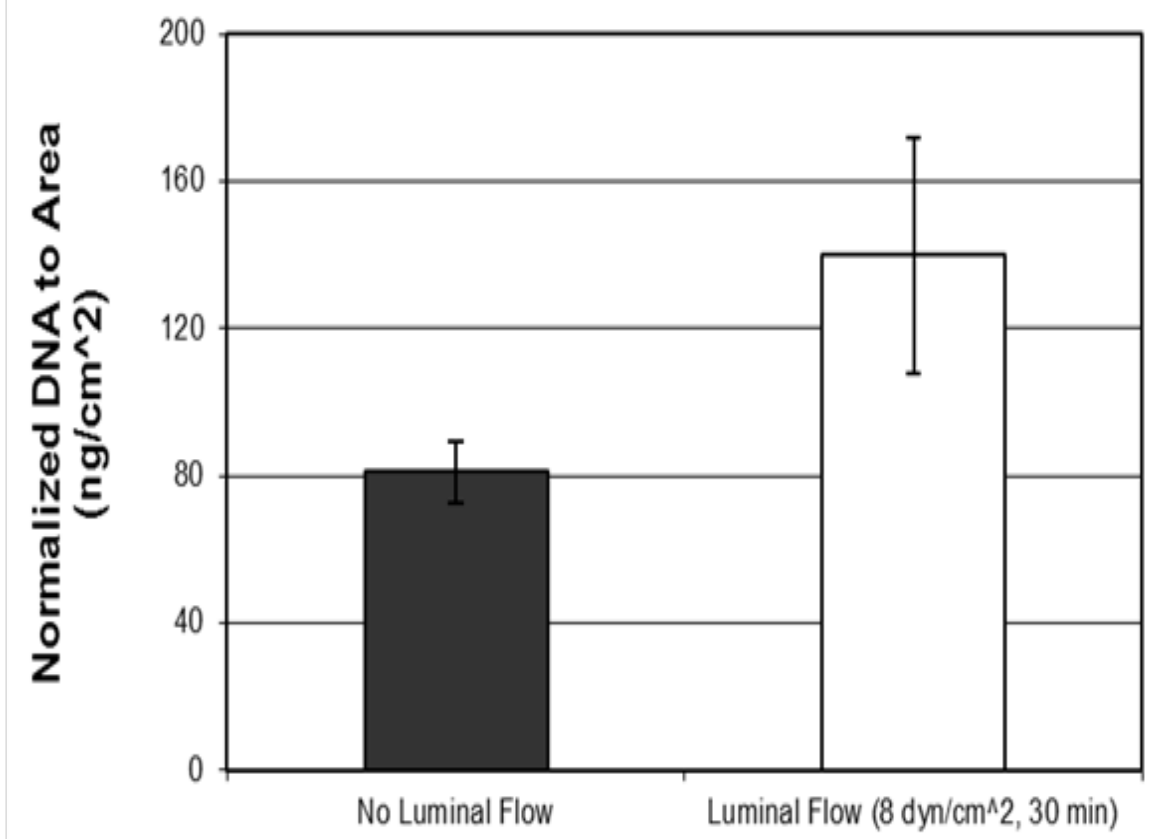

Post-Sodding Treatment

B

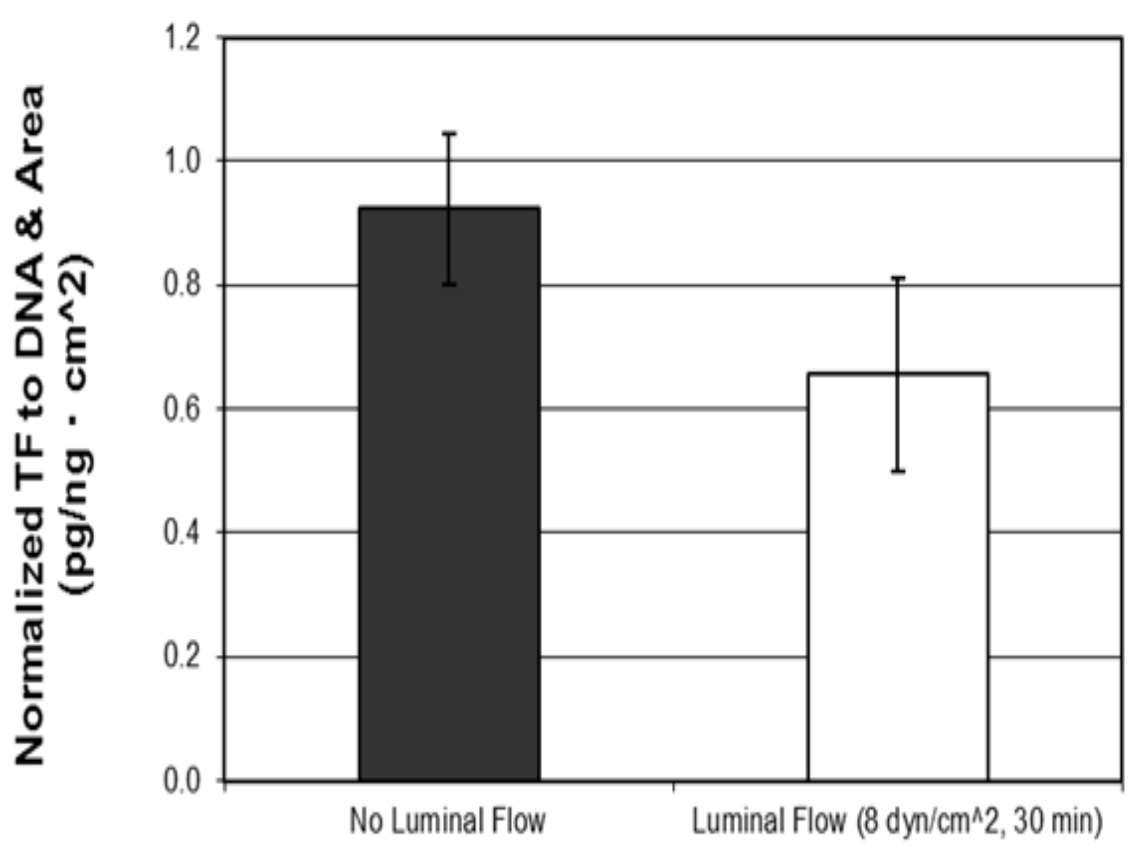

Post-Sodding Treatment

Figure 5 Effects of luminal flow applied post sodding of freshly isolated SVF cells onto the ePTFE conduit. (A) Normalized DNA quantity to the luminal area of the grafts and (B) normalized tissue factor to the luminal area and total DNA. Data is shown as mean $\pm S E$; no luminal flow ( $n=5$ ), luminal flow ( $n=6$ ). 

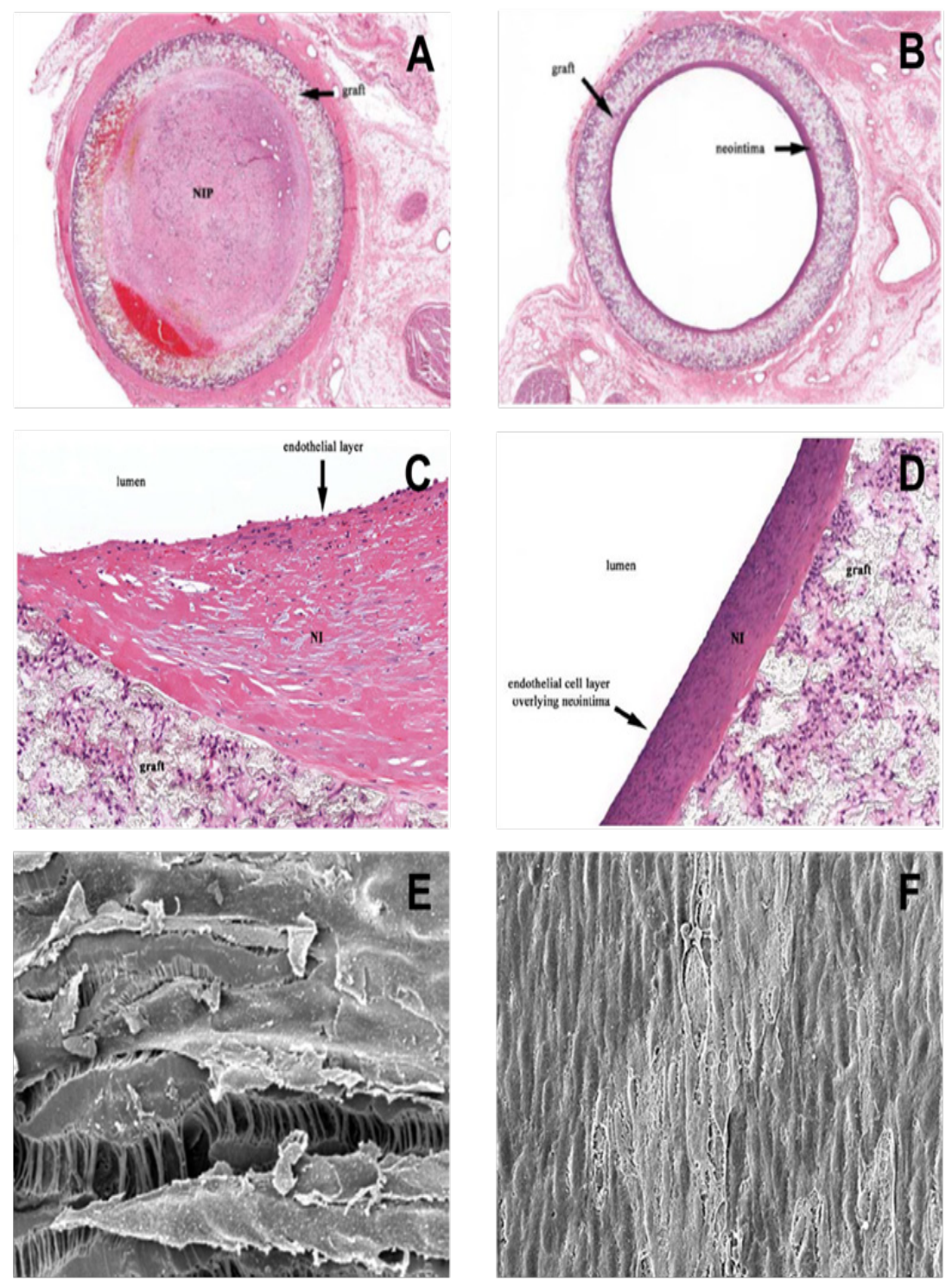

Figure $6(A)-(D)$ Histological images of control $(A, C)$ and cell-sodded $(B, D)$ vascular grafts. $(E)-(F)$ Scanning electron micrographs of the luminal surface of control $(E)$ and cell-sodded $(F)$ vascular grafts.

\section{Conclusion}

The study illustrates the feasibility of pressure sodding cells onto permeable tubular scaffolds using a continuous pressure, low flow environment generated by an automated bioreactor flow system (Bio-Optimization System; BOS). The ability of ASCs to withstand physiological shear within a vascular graft after sodding was also established.

The seeding density of $5 \times 10^{5} \mathrm{ASCs} / \mathrm{cm}^{2}$ was sufficient to obtain over $80 \%$ cell coverage consistently upon pressure sodding for as few as 5 minutes. A statistically significant decrease in total DNA quantity upon exposure to a luminal flow at a physiological shear level for 30 minutes indicated that some cells had detached from the conduit surface. When grafts were sodded at $5 \times 10^{5} \mathrm{ASCs} / \mathrm{cm}^{2}$, some access cells were suspected of producing overlapping multiple layers of cells that were not in direct contact with the luminal surface, suggesting cell density was too high. Cells residing on top of other ASCs rather than directly to the graft conduit surface following sodding may be

more vulnerable to detachment upon the initiation of luminal flow, causing the failure of cell coverage in some grafts. Tissue factor level normalized to total DNA and cell coverage on the luminal surface of the conduit did not increase significantly with luminal flow, suggesting grafts may withstand physiological shear of approximately 8dynes/ $\mathrm{cm}^{2}$ without significantly increasing the risk of an adverse thrombotic response following implantation into a patient.

In the second set of experiments, feasibility of lowering cell sodding density to $2 \times 10^{5} \mathrm{ASCs} / \mathrm{cm}^{2}$ was examined. Lowering the sodding density subsequently reduces the total number of cells required for the graft endothelialization and autologous adipose tissue harvests by as much as $60 \%$, while maintaining the adequate cell coverage of a vascular conduit. The grafts sodded at $2 \times 10^{5} \mathrm{ASCs} / \mathrm{cm}^{2}$ showed adequate cell coverage of over $80 \%$ based on BBI staining. Normalized tissue factor upon pressure sodding was also significantly lower when the conduits were sodded at $2 \times 10^{5} \mathrm{ASCs} / \mathrm{cm}^{2}$ compared to sodding at $5 \times 10^{5} \mathrm{ASCs} / \mathrm{cm}^{2}$. We speculate that utilizing fewer cells permitted more cellular spreading toward a morphology that 
is analogous to natural endothelium. This can subsequently reduce clumping of cells into multiple loose layers of cells within the grafts as seen in the graft sodded at $5 \times 10^{5}$ cells $/ \mathrm{cm}^{2}$. These cumulative effects may have ultimately lowered tissue factor production when grafts were sodded at $2 \times 10^{5}$ cells $/ \mathrm{cm}^{2}$. Based on these results, we have determined that $2 \times 10^{5}$ cells $/ \mathrm{cm}^{2}$ is an optimal cell sodding density.

Once the optimal cell sodding density was ascertained, freshlyisolated SVF cells were tested in order to evaluate a practical point-ofcare method of vascular graft fabrication. One of the major challenges for tissue-engineered vascular grafts is the prolonged in-vitro culture necessary to expand cell populations for endothelialization and to stabilize cell adhesion to the substrate in an effort to maximize the retention of seeded cells to the prosthetic surface. ${ }^{13}$ This study demonstrated that freshly-isolated SVF cells can be used immediately to eliminate the need for prolonged in-vitro culture. Adipose tissue is relatively simple to procure and abundant in humans even with low body fat content. Therefore, a large population of autologous SVF cells can be easily obtained. For a 4-mm inner diameter conduit, 0.25 million cells were required per $10 \mathrm{~mm}$ graft length when sodded at $2 \times 10^{5}$ cells $/ \mathrm{cm}^{2}$. Approximately 0.8 million viable SVF cells were isolated from 1 gram of freshly lipoaspirated adipose tissue. Therefore, less than 20grams of adipose tissue would be sufficient to endothelialize a $50 \mathrm{~cm}$ vascular graft. Normalized total DNA (Figure $5 \mathrm{~A}$ ) indicated that sodded SVF cells remained intact following the application of luminal flow. In addition, increases in tissue factor level were not observed when grafts were subjected to luminal flow in contrast to the vascular grafts sodded at $5 \times 10^{5}$ cells $/ \mathrm{cm}^{2}$ (Figure 5B).

Based on the limitations of cultured ASCs and the benefits of SVF cells observed in the earlier stages of this study, we had decided to test freshly-isolated SVF cell-sodded grafts in animals. Previously reported studies demonstrated that vascular grafts under $6 \mathrm{~mm}$ in diameter are difficult to maintain patency in vivo. Compared to the control naked conduits, $100 \%$ of cell-sodded vascular grafts implanted into common carotid arteries remained patent after $140 \pm 1$ days with minimal neointima formation and cellular erosion.

In this study, cell-lined vascular grafts were produced by a lowpressure, continuous flow-sodding process using ePTFE conduits as a scaffold. The sodding process utilized either freshly-isolated adipose SVF cells or in-vitro cultured ASCs and was completed within 5 minutes. Over $80 \%$ of the luminal area of each conduit was homogeneously covered with adipose derived SVF (ASC) cells. The cellular lining remained intact following exposure to luminal fluid shear at 8 dynes $/ \mathrm{cm}^{2}$ without increasing tissue factor production by the cells. The rapid fabrication and the utility of the vascular grafts formed were clearly demonstrated as a potential point-of-care treatment for various vascular diseases. Advancements in automated SVF cell isolation ${ }^{24,25}$ and vascular conduit materials can have a tremendous impact on clinical utility of these vascular grafts. ${ }^{26-28}$

\section{Acknowledgements}

Authors would like to thank Mrs. Alice Stone for her technical assistance in cell isolation. This study was supported by the United States Army Medical Research and Material Command through Department of Defense Contract W81XWH-04-1-0503.

\section{Conflict of interest}

The author declares no conflict of interest.

\section{References}

1. Yanagisawa T, Shimizu T, Kuroda K, et al. The preparation of alkyltrimethylammonium-kanemite complexes and their conversation to microporous materials. Bull Chem Soc Jpn. 1990;63(4):988-992.

2. Kresge CT, Leonowicz ME, Roth WJ, et al. Ordered mesoporous molecular sieves synthesized by a liquid-crystal template mechanism. Nature. 1992;359:710-712.

3. Vallet Regí M. Nanostructured mesoporous silica matrices in nanomedicine. J Intern Med. 2010;267(1):22-43.

4. Vallet Regí M, Rámila A, del Real RP, et al. A new property of MCM41: drug delivery system. Chem Mater. 2001;13:308-311.

5. Vallet-Regí M, Balas F, Arcos D. Mesoporous materials for drug delivery. Angew Chem Int Ed. 2007;46(40):7548-7558.

6. Gao C, Qiu H, Zeng W, et al. Formation mechanism of anionic surfactanttemplated mesoporous silica. Chem Mater. 2006;18(116):3904-3914.

7. Garcia-Bennett AE, Kozhevnikova M, König N, et al. Delivery of differentiation factors by mesoporous silica particles assists advanced differentiation of transplanted murine embryonic stem cells. Stem Cells Transl Med. 2013;2(11):906-915.

8. Vallhov H, Gabrielsson S, Stromme M, et al. Mesoporous silica particles induce size dependent effects on human dendritic cells. Nano Lett. 2007;7(12):3576-3582.

9. Santos T, Maia J, Agasse F, et al. Nanomedicine boosts neurogenesis: new strategies for brain repair. Integr Biol. 2012;4(9):973-981.

10. Lu J, Liong M, Li Z, et al. Biocompatibility, biodistribution, and drugdelivery efficiency of mesoporous silica nanoparticles for cancer therapy in animals. Small. 2010;6(16):1794-1805.

11. Maro GS, Vermeren M, Voiculescu O, et al. Neural crest boundary cap cells constitute a source of neuronal and glial cells of the PNS. Nat Neurosci. 2004;7(9):930-938.

12. Hjerling Leffler J, Marmigère F, Heglind M, et al. The boundary cap: a source of neural crest stem cells that generate multiple sensory neuron subtypes. Development. 2005;132(11):2623-2632.

13. Bron R, Vermeren M, Kokot N, et al. Boundary cap cells constrain spinal motor neuron somal migration at motor exit points by a semaphorinplexin mechanism. Neural Dev. 2007;2:21.

14. Kucenas S, Wang WD, Knapik EW, et al. A selective glial barrier at motor axon exit points prevents oligodendrocyte migration from the spinal cord. J Neurosci. 2009;29(48):15187-15194.

15. Coulpier F, Decker L, Funalot B, et al. CNS/PNS boundary transgression by central glia in the absence of Schwann cells or Krox20/Egr2 function. J Neurosci. 2010;30(17):5958-5967.

16. Gresset A, Coulpier F, Gerschenfeld G, et al. Boundary caps give rise to neurogenic stem cells and terminal glia in the kkin. Stem Cell Rep. 2015;5(2):278-290.

17. Zujovic V, Thibaud J, Bachelin C, et al. Boundary cap cells are highly competitive for CNS remyelination: fast migration and efficient differentiation in PNS and CNS myelin-forming cells. Stem Cells. 2010;28(3):470-479.

18. Zujovic V, Thibaud J, Bachelin C, et al. Boundary cap cells are peripheral nervous system stem cells that can be redirected into central nervous system lineages. Proc Natl Acad Sci USA. 2011;108(26):10714-10719.

19. Trolle C, Konig N, Abrahamsson N, et al. Boundary cap neural crest stem cells homotopically implanted to the injured dorsal root transitional zone give rise to different types of neurons and glia in adult rodents. BMC Neurosci. 2010;15:60. 
20. Grouwels G, Vasylovska S, Olerud J, et al. Differentiating neural crest stem cells induce proliferation of cultured rodent islet beta cells. Diabetologia. 2012;55(7):2016-2025.

21. Ngamjariyawat A, Turpaev K, Welsh N, et al. Coculture of insulinproducing RIN5AH cell with neural crest stem cells protects partially against cytokine-induced cell death. Pancreas. 2012;41(3):490-492.

22. Olerud J, Kanaykina N, Vasylovska S, et al. Neural crest stem cells increase beta cell proliferation and improve islet function in cotransplanted murine pancreatic islets. Diabetologia. 2009;52(12):25942601 .

23. Garcia Bennett AE, Xiao C, Chunfang Z, et al. Bicontinuous cubic mesoporous materials with biphasic structures. Chemistry. 2011;17(48):13510-13516.

24. Atluri R, Hedin N, Garcia Bennett AE. Hydrothermal phase transformation of bicontinuous cubic mesoporous material AMS-6. Chem Mater. 2008;20(12):3857-3866.
25. Witasp E, Kupferschmidt N, Bengtsson L, et al. Efficient internalization of mesoporous silica particles of different sizes by primary human macrophages without impairment of macrophage clearance of apoptotic or antibody-opsonized target cells. Toxicol Appl Pharmacol. 2009;239(3):306-319.

26. Rønn L, Ralets I, Hartz B, et al. A simple procedure for quantification of neurite outgrowth based on stereological principles. J Neurosci Meth. 2000;100(1-2):25-32.

27. Chang JS, Chang KLB, Hwang DF, et al. In vitro cytotoxicitiy of silica nanoparticles at high concentrations strongly depends on the metabolic activity type of the cell line. Envir Sci Technol. 2007;41(6):2064-2068.

28. Chen M, Mikecz A. Formation of nucleoplasmic protein aggregates impairs nuclear function in response to $\mathrm{SiO}_{2}$ nanoparticles. Exp Cell Res. 2005;305(1):51-62. 